\title{
DETERMINATION OF VANCOMYCIN BY USING RP-HPLC METHOD IN PHARMACEUTICAL PREPARATIONS
}

\author{
K.Nirmala and R. Ramesh Raju* \\ Department of Chemistry, Acharya Nagarjuna University, Nagarjuna Nagar, Guntur, Andhra Pradesh, India
}

Received on: 09/10/12 Revised on: 20/11/12 Accepted on: 10/12/12

\author{
*Corresponding author \\ E-mail: rrraju1@gmail.com \\ DOI: 10.7897/2277-4343.04139 \\ Published by Moksha Publishing House. Website www.mokshaph.com \\ All rights reserved.
}

\section{ABSTRACT}

A novel, simple and economic reverse phase high performance liquid chromatography (RP-HPLC) method has been developed for the estimation of vancomycin in tablet dosage forms with high precision and accuracy. Sample separation was achieved on C18 column (250 X $4.6 \mathrm{~mm}$ i.d., $5 \mu \mathrm{m})$ in isocratic mode using methanol, Acetonitrile (ACN) and $0.1 \%$ Ortho phosphoric acid (OPA) in the ratio (25:72:3) (v/v/v) as mobile phase, pumped in to the column at flow rate of $1 \mathrm{ml} / \mathrm{min}$ and the detection of eluent from the column was carried out using variable wavelength detector at $229 \mathrm{~nm}$. The total run time was $7 \mathrm{~min}$ and the column was maintained at ambient temperature. The retention time of Vancomycin was 2.822 min. The standard curves were linear over the concentration range of $2-12 \mu \mathrm{g} / \mathrm{ml}$ and the LOD and LOQ values for Vancomycin were 0.1 and 0.03 respectively. The recovery was found to be 99 percent and the \% RSD of intraday and inter day precision was found less than $2 \%$, respectively. The percentage amount of two different marketed tablet formulation of Vancomycin was found to be $99.5 \%$. The method was validated as per ICH (International council of Hormonisation) guidelines. Validation studies demonstrated that the proposed RP-HPLC method is simple, specific, rapid, reliable and reproducible. The high recovery and low relative standard deviation confirm the suitability of the proposed method for the routine quality control analysis of Vancomycin in tablet dosage forms.

Keywords: Vancomycin, RP-HPLC, ICH guidelines, Validation and C18column.

\section{INTRODUCTION}

Vancomycin was first isolated in 1953 by Edmund Kornfeld from a soil sample collected from the interior jungles of Borneo ${ }^{1}$. Amycolatopsis orientalis is main constituent of vancomycin and it plays the key role for treatment ${ }^{2}$. The original indication for vancomycin was for the treatment of pencillin resistant Staphylococcus aureus $^{2,3}$. Vancomycin is a glycopeptides antibiotic being isolated from both Steptomyces orientalis and Nocardia lurida. It was introduced in 1956 because of its strong bactericidal activity against many gram-positive bacteria, particularly Staphylococus aureus. Because of its toxicity, Vancomycin was relegated to the role of alternate therapy when antibiotics such as methicillin became available $e^{4,5,6}$.

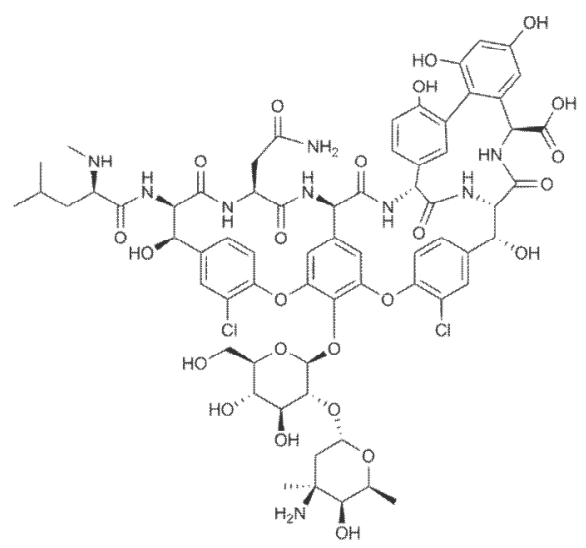

Figure 1: Structure of Vancomycin

Molecular formula of vancomycin is $\mathrm{C}_{66} \mathrm{H}_{75} \mathrm{Cl}_{2} \mathrm{~N}_{9} \mathrm{O}_{24}$ and molecular weight is 1449.3 g. $\mathrm{mol}^{-1}$. Structure of vancomycin is given in Figure 1. Vancomyicin is used for full time treatment for the severe infection and susceptible strains due to methicillin resistant staphylococci (MRSA) virus, the increasing number of methicillin-resistant isolates of S.aureus, Staphylococcus epidermidis ${ }^{7-10}$ and Streptococcus pneumoniae ${ }^{11}$. Similar to problems of treating patients allergic to beta-lactam antibiotics, led to the rehabilitation of vancomycin ${ }^{7,9,12}$. In addition, it seems that much of the toxicity was due to impure preparations 9 . It is indicated for penicillin allergic patients, especially those who cannot receive or have failed to respond to other drugs including penicillins or cephalosporins. Vancomycin is not active In-vitro against Gram negative bacilli, mycobacteria and fungi, bactericidal action results inhibition of cell wall biosynthesis and also alters the bacterial cell membrane permeability and RNA synthesis. There is no cross resistance between vancomycin and other antibiotics. Many microbiological assay procedures lasting from 24 to $48 \mathrm{~h}$ have been developed for monitoring vancomycin ${ }^{11,13,14}$. Radioimmunoassay (RIA) and fluorescent polarization immunoassay (FPIA) have been developed ${ }^{15,16}$ and two chromatographic procedures have also been described ${ }^{17,18,19}$. The present report describes a simple, accurate, and very sensitive highpressure liquid chromatographic assay (HPLC) and it was used commonly in hospitals.

\section{MATERIAL AND METHODS Drugs and Chemicals}

Working standard of vancomycin was obtained from well reputed research laboratories. HPLC grade water, methanol, 0.1\% Ortho Phosphoric Acid (OPA) was purchased from E. Merck (Mumbai, India). 


\section{Instrumentation}

A Series HPLC system PEAK LC7000 isocratic HPLC with PEAK 7000 delivery system. Rheodyne manual sample injector with switch (77251), Analytical column Chromosil C18. $250 \times 4.6 \mathrm{~mm}$, Electronic balanceDENVER (SI234), a manual Rheodyne injector with a 20 $\mu$ loop was used for the injection of sample. PEAK LC software was used to analysis of the HPLC PEAK and UV 2301 Spectrophotometer was used to determine the wavelength of maximum absorbance of drug.

Determination of wavelength of maximum absorbance The standard solutions of Vancomycin were scanned in the range of $200-400 \mathrm{~nm}$ against mobile phase as a blank.Vancomycin showed maximum absorbance at 229 $\mathrm{nm}$. So the wavelength selected for the determination of Vancomycin was 229nm.

\section{Chromatographic equipment and conditions}

The development and validation of the assay was performed on $\alpha$ Series HPLC system PEAK LC7000 isocratic HPLC with PEAK 7000 delivery system. Rheodyne manual sample injector with switch (77251), Analytical column Chromosil C18. 250×4.6mm, manual injector Rheodyne valve with $20 \mu \mathrm{L}$ fixed loop, PEAK LC software was used.

The mobile phase consisting of Methanol, acetonitrile (HPLC grade) and $0.1 \%$ OPA were filtered through $0.45 \mu$ membrane filter before use, degassed and were pumped from the solvent reservoir in the ratio of 25:72:3 (v/v/v) into the column at a flow rate of $1 \mathrm{ml} / \mathrm{min}$. The detection was monitored at $229 \mathrm{~nm}$ and the run time was $7 \mathrm{~min}$. The volume of injection loop was $20 \mu \mathrm{l}$. Prior to injection of the drug solution the column was equilibrated for at least 30 min with the mobile phase flowing through the system. The column and the HPLC system were kept in ambient temperature

\section{Standard and sample solutions}

Standard solution was prepared by adding $10 \mathrm{mg}$ amount of Vancomycin. Drug was used accurately weighed and dissolved in $10 \mathrm{ml}$ mobile phase in volumetric flask to get $1000 \mathrm{ppm}$ and it is standard solution. From the standard solution on serial dilutions 100ppm concentration was prepared. 20 tablets of Vancomycin were grinded to a fine, unifom size powder. From this powder approximately $25 \mathrm{ml}$ mobile phase were added then the solution was sonicated for $30 \mathrm{~min}$. The flask was filled to volume with mobile phase and mixed well and filtered. After filtration an amount of the solution was diluted with mobile phase to concentration up to $6 \mathrm{ppm}$.

\section{RESULT AND DISCUSSION \\ System Suitability}

Having optimized the efficiency of a chromatographic separation, the quality of the chromatography was monitored by applying the following system suitability tests, tailing factor and theoretical plates. The system suitability method acceptance criteria set in each validation run were, tailing factor $\leq 2.0$ and theoretical plates $>2000$. In all cases, the relative standard deviation (R.S.D) for the analytic peak area for two consecutive injections was $<2.0 \%$. A chromatogram obtained from reference substance solution is presented. System suitability parameters were shown in Table 1 and standard chromatogram was given in Figure 2.

\section{Validation}

Method validation was performed according to $\mathrm{ICH}$ (International council of Hormonisation) guidelines for specificity, range of linearity, accuracy, precision and robustness.

Table 1: Column parameters and values

\begin{tabular}{|c|c|}
\hline Test & Result \\
\hline Elution & Isocratic \\
\hline A.P.I Conc & $6 \mathrm{ppm}$ \\
\hline Mobile Phase & $\mathrm{MeOH}:: \mathrm{ACN}: 0.1 \%$ OPA $(25: 72: 3)$ \\
\hline $\mathrm{pH}$ & 5.4 \\
\hline Column & $\mathrm{C} 18$ \\
\hline Wave Length & $229 \mathrm{~nm}$ \\
\hline Flow Rate & $1 \mathrm{ml} / \mathrm{min}$ \\
\hline Runtime & $7 \mathrm{~min}$ \\
\hline Retention Time & 2.822 \\
\hline Area & 193908 \\
\hline Theoretical Plates & 6829 \\
\hline Tailing Factor & 1.08 \\
\hline Pump Pressure & $21.2 \mathrm{psi}$ \\
\hline
\end{tabular}

Table 2: Peak area and RSD determination of system

\begin{tabular}{|c|c|c|c|c|}
\hline Conc 6 ppm & \multicolumn{2}{|c|}{ Precision 1 } & Precision 2 \\
\hline Day -1 & Injection & Area-1 & Area-2 & \multirow{2}{*}{ R.S.D1 $=0.611$} \\
\cline { 2 - 4 } & 1 & 193766 & 196035 & \multirow{3}{*}{ R.S.D 2 $=0.25$} \\
\cline { 2 - 4 } Day-2 & 2 & 195120 & 195565 & \\
\cline { 2 - 4 } & 3 & 196133 & 195151 & \\
\cline { 2 - 4 } & 4 & 196495 & 195120 & \\
\cline { 2 - 4 } & 5 & 196556 & 195949 & \\
\cline { 2 - 4 } & 6 & 196983 & 196303 & \\
\hline
\end{tabular}

Table 3: Range of Linearity

\begin{tabular}{|c|c|c|}
\hline Conc. in ppm & Area & \multirow{2}{*}{ Intercept $=3147$} \\
\hline 2 & 63795 & \\
\hline 4 & 127610 & \multirow{2}{*}{ Slope $=30979$} \\
\hline 6 & 193909 & \\
\hline 8 & 252381 & \multirow{2}{*}{ C.C $=0.9994$} \\
\hline 10 & 318772 & \\
\hline 12 & 366713 & \\
\hline
\end{tabular}

Table 4: Limit of Detection and Limit of Quantification \begin{tabular}{|c|c|c|}
\hline Test-4 & L.O.Q & $0.03 \mathrm{ppm}$ \\
\hline Test-5 & L.O.D & $0.1 \mathrm{ppm}$ \\
\hline
\end{tabular}

Table 5: Robustness Study

\begin{tabular}{|c|c|c|c|}
\hline Parameter & Modification & Peak Area & \% of change \\
\hline M.Phase & $\begin{array}{c}\text { MeOH ::ACN:0.1\% } \\
\text { OPA(30:67:3) }\end{array}$ & 195492 & 0.816 \\
\hline pH & 5.7 & 196278 & 1.22 \\
\hline Wavelength & 234 & 196647 & 1.41 \\
\hline
\end{tabular}

Table 6: Recovery Study

\begin{tabular}{|c|c|c|c|}
\hline Recovery & Conc. of sample & Recovery & \% of recovery \\
\hline $50 \%$ & $4 \mathrm{ppm}$ & 3.975 & 99.38 \\
\hline $100 \%$ & $8 \mathrm{ppm}$ & 7.91 & 98.87 \\
\hline $150 \%$ & $12 \mathrm{ppm}$ & 11.95 & 99.58 \\
\hline
\end{tabular}

Table 7: Drug Estimation

\begin{tabular}{|c|c|c|c|c|}
\hline Brand & Strength & $\begin{array}{c}\text { Sample } \\
\text { concentration }\end{array}$ & $\begin{array}{c}\text { Amount } \\
\text { estimated }\end{array}$ & $\begin{array}{c}\text { \% of drug } \\
\text { estimated }\end{array}$ \\
\hline $\begin{array}{c}\text { Vancocin } \mathrm{HCl} \\
\text { Capsules }\end{array}$ & $250 \mathrm{mg}$ & $6.0 \mathrm{ppm}$ & $5.97 \mathrm{grms}$ & 99.50 \\
\hline
\end{tabular}




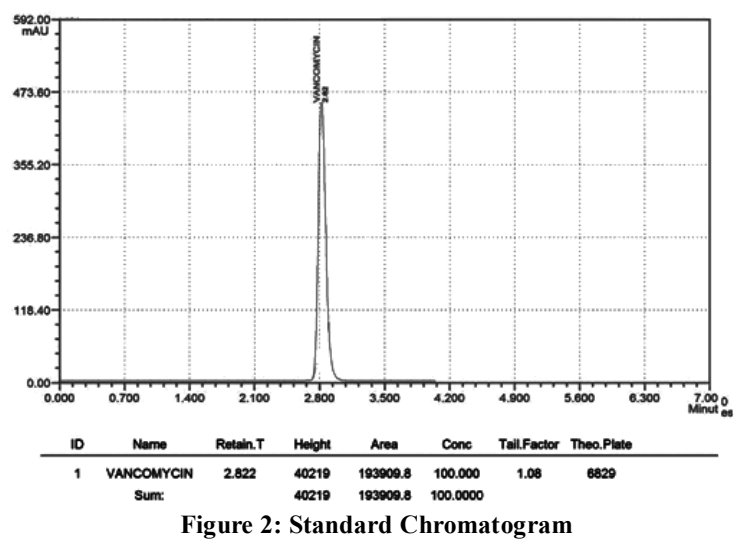

\section{Accuracy}

The accuracy of the HPLC method was assessed by adding known amount of drug solution to a drug solution of known concentration and subjecting the samples to the proposed HPLC method.

\section{Precision}

To study precision, six replicate standard solutions of Vancomycin (6ppm) were prepared and analyzed using the proposed method. The percent relative standard deviation (\% RSD) for peak responses was calculated and it was found to be within the acceptance criteria of not more than $2.0 \%$. Results of system precision studies are shown in Table 2.

$$
\% \mathrm{RSD}=\frac{\mathrm{STD} \operatorname{dev} \text { of } \mathrm{X} 100 \%}{\text { Mean }}
$$

\section{Range of linearity}

Standard curves were constructed daily, for three consecutive days, using seven standard concentrations in a range of 2, 4, 6, 8, 10,12, $\mu \mathrm{g} / \mathrm{ml}$ for Vancomycin. The linearity of peak area responses versus concentrations was demonstrated by linear least square regression analysis. The linear regression equation was $(\mathrm{y}=\mathrm{mx}+\mathrm{c})$ where $\mathrm{m}=$ slope and $\mathrm{c}=$ intercept; $\mathrm{y}=3147+30979 \mathrm{x} \quad(\mathrm{r}=$ $0.9994)$. Linearity values can show in Table 3.

\section{Limit of Detection and Limit of Quantification}

To determine the Limit of Detection (LOD) sample was dissolved by using Mobile phase and injected until peak was disappeared. After $0.1 \mathrm{ppm}$ dilution Peak was not clearly observed, based on which $1.5 \mathrm{ppm}$ is considered as Limit of Detection and Limit of Quantification is 0.03 ppm and the values are given in Table 4 .

\section{Robustness: Conc.:6 ppm}

Typical variations in liquid chromatography conditions were used to evaluate the robustness of the assay method. In this study, the chromatographic parameters monitored such as retention time, area, tailing factor and theoretical plates. The robustness acceptance criteria set in the validation were the same established on system suitability test describes the Robustness and given in the Table 5.

\section{Recovery}

Recovery test was performed at 3 different concentrations i.e., $4 \mathrm{ppm}, 8 \mathrm{ppm}$ and $12 \mathrm{ppm}$. The accuracy was expressed in terms of recovery and calculated by multiplying the ratio of measured drug concentration compare to the

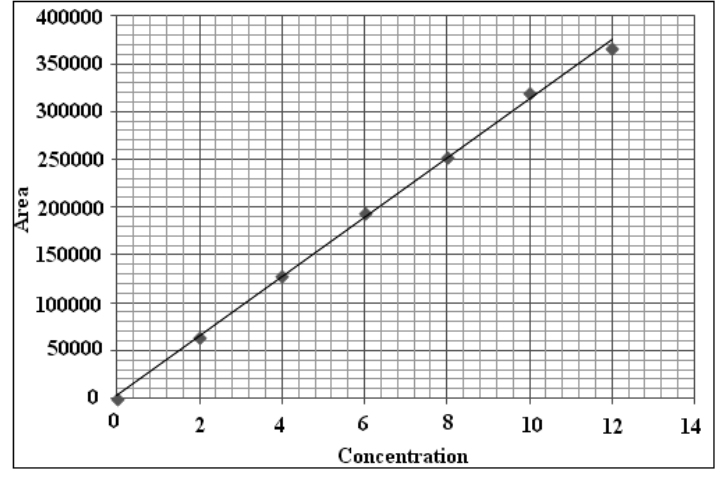

Figure 3: Linearity of Vancomycin

expected drug concentration, so as to give the percentage of recovery. Results are given in Table 6 .

\section{Formulation}

(Table 7)

\section{CONCLUSION}

The proposed method for the assay of Vancomycin in tablets or capsules is very simple and rapid. It should be emphasized that it is isocratic and the mobile phase do not contain any buffer. The method was validated for specificity, linearity, precision, accuracy and robustness. Although the method could effectively separate the drug from its products, further studies should be performed in order to use it and to evaluate the stability of pharmaceutical formulations.

\section{REFERENCES}

1. Shnayerson, Michael; Plotkin, Mark. The Killers within: The Deadly Rise of Drug-Resistant Bacteria. Back Bay books 2003

2. Levine D. Vancomycin: A History. Clin Infect Dis 2006; 42:5-12 http://dx.doi.org/10.1086/491709 PMid:16323120

3. Moellering RC Jr. Vancomycin: A 50-Year Reassessment". Clin Infec Dis. 2006;42(1):3-4 http://dx.doi.org/10.1086/491708 PMid:16323117

4. Cafferkey MT, R Hone and CT Keane. Severe staphylococcal infections treated with vancomycin. J. Antimicrob. Chemother. 1982; 9:69-74 http://dx.doi.org/10.1093/jac/9.1.69 PMid:7061356

5. Fekety R. Vancomycin. Med. Clin. North Am. 1982; 66:175-181

6. Geraci JE and PE Hermans. Vancomycin. MayoClin. Proc. 1983; 58:88-91 PMid:6823162

7. Cook FV and WE Farrar. Vancomycin revisited.Ann. Intern. Med. 1978; 88:813-18. PMid:352213

8. Cunha BA, R Quintiliani, JM Deglin, $\mathrm{MW}$ hard and $\mathrm{CH}$ Nightingale. Pharmacokinetics of vancomycin in anuria. Rev. Infect. Dis. 1981; 3:S269-S272 http://dx.doi.org/10.1093/ clinids/3.Supplement.S269 PMid:7342290

9. Engineer MS, DW Ho and GP Bodey, Sr. Comparison of vancomycin disposition in rats with normal and abnormal renal functions. Antimicrob. Agents Chemother. 1981;20:718-722 http://dx.doi.org/10.1128/AAC.20.6.718 $\quad$ PMid:7325638 PMCid: 181788

10. Norden CW and M Shaffer. Treatment of experimental chronic osteomyelitis due to Staphylococcus aureus with vancomycin and rifampin. J. Infect. Dis. 1983; 147:352-357 http://dx.doi.org/ 10.1093/infdis/147.2.352 PMid:6827150

11. Beam TR. Vancomycin therapy of experimental pneumococcal meningitis caused by Penicillin-sensitive and resistant strains. J. Antimicrob. Chemother 1981;7(1): 89-99 http://dx.doi.org/ 10.1093/jac/7.1.89 PMid:6907271

12. Brown N, DHW Ho, KL Fong, L Bogerd, A Maksymiuk, R Bolivar, $\mathrm{V}$ Fainstern and GP Bodey. Effects of hepatic function on vancomycin clinical pharmacology. Antimicrob. Agents Chemother. 1983:23:603-609 http://dx.doi.org/10.1128/AAC.23.4.603 PMid:6859839 PMCid: 184709 


\section{R. Ramesh Raju et al / IJRAP 4(1), Jan - Feb 2013}

13. Heckerman HG Berg, RG Strate and JC Rotschafer. Comparison of radioimmunoassay and fluorescent polarization immunoassay for quantitative determination of vancomycin concentrations in serum. $\mathrm{J}$ Clin Microbiol. 1983 October; 18(4): 994-995

14. Pharmacokinetics of vancomycin J. Antimicrob. Chemother 1984;14(D): 43-52 http://dx.doi.org/10.1093/jac/14.suppl D.43

15. Jack Brown, Kristen Brown and Alan Forrest Antimicrob Agents Chemother. 2012 February; 56(2): 634-638 http://dx.doi.org/ 10.1128/AAC.05609-11 PMid:22123681 PMCid:3264249

16. Biju Raju, Geetha Thiagarajan, Taraprasad Das and the Hyderabad Endophthalmitis Research Group Modified High-Performance Liquid Chromatography Technique for Detection of Vancomycin in Human Vitreous Ophthalmic Res 2004;36:55-61

17. Fong KLL, DWHo, L Bogerd, T Pan, NS Brown, L Gentry and GP Bodey Sr. Sensitive radioimmunoassay for vancomycin.
Antimicrob. Agents Chemother. 1981;19:139-143 http://dx.doi.org 10.1128/AAC.19.1.139 PMid:7247352 PMCid:181372

18. Francois Jehl, Corinne Gallion, Robert C Thierry and Henri Monteil. Determination of Vancomycin in Human Serum by HPLC Antimicro and chemo, 1985: 27: 503-507

19. Uhl JR and JP Anhalt. High performance liquid chromatographic assay of Vancomycin in serum. Ther. Drug Monit 1979;1:75-83 http://dx.doi.org/10.1097/00007691-197901000-00008 PMid:553332

Cite this article as:

K.Nirmala and R. Ramesh Raju. Determination of Vancomycin by using RP-HPLC method in pharmaceutical preparations. Int. J. Res. Ayur. Pharm. 2013; 4(1):116-119 